\title{
PENGGUNAAN INFORMASI YANG BERSIFAT RAHASIA OLEH KARYAWAN KEPADA PERUSAHAAN SESAMA PESERTA TENDER DIHUBUNGKAN DENGAN PRINSIP KERAHASIAAN DAN UNDANG- UNDANG NOMOR 30 TAHUN 2000 TENTANG RAHASIA DAGANG JUNCTO UNDANG-UNDANG NOMOR 13 TAHUN 2003 TENTANG KETENAGAKERJAAN
}

\author{
Anwar Hidayat \\ Program Pascasarajana Universitas Islam Bandung \\ Email: AnwarHidayat75@yahoo.com
}

\begin{abstract}
ABSTRAK
Persaingan merupakan bagian yang tidak terpisahkan dari kehidupan yang dihadapi para pengusaha dalam mencapai tujuan yaitu memperoleh laba yang sebesar-besarnya dan mengungguli perusahaan lain serta menjaga perolehan laba tersebut. Pelanggaran terhadap rahasia dagang sering terjadi baik antara pengusaha dengan pengusaha, pengusaha dengan perorangan maupun pengusaha dengan karyawannya. Berdasar pada latar belakang tersebut maka muncul permasalahan yang akan dikaji yakni bagaimana penggunaan informasi yang bersifat rahasia dan tanggung jawab kerahasiaan perusahaan oleh karyawan dihubungkan dengan prinsip kerahasiaan dan Undang-undang No 30 Tahun 2000 Tentang Rahasia Dagang Jo Undang-undang No 13 Tahun 2003 Tentang ketenagakerjaan.

Rahasia dagang merupakan salah satu dari hak kekayaan intelektual yang diberikan perlindungan oleh negara melalui peraturan perundang-undangan. Akan tetapi akibat dari persaingan usaha yang tidak sehat diantara para pelaku bisnis khususnya persaingan usaha di bidang bisnis kontruksi pembangunan fasilitas umum, membuat para pelaku usaha menggunakan segala cara untuk memenangkan tender yang diadakan oleh penyelenggara tender termasuk dengan atau tanpa hak menggunakan informasi rahasia milik perusahaan lain guna mendapatkan keuntungan yang sebesar-besarnya. Cara yang digunakan untuk mendapatkan informasi rahasia yang bernilai ekonomis dilakukan dengan berbagai cara salah satunya dengan memanfaatkan pekerja/karyawan perusahaan pemilik informasi yang berkewajiban menjaga informasi. Persoalannya bagaimana penggunaan informasi yang bersifat rahasia oleh karyawan berdasarkan prinsip kerahasiaan dan bagaimana tanggung jawab karyawan yang menggunakan informasi rahasia di bidang jasa kontruksi.
\end{abstract}

Kata Kunci: Informasi Rahasia, Tanggung Jawab Karyawan 


\begin{abstract}
Competition is an integral part of the life faced by entrepreneurs in achieving the objective of obtaining maximum profits and outperform other companies and keep the profit. Violation of trade secrets often occurs between businessmen with businessmen, entrepreneurs with individuals and employers with employees. Based on this background, the emerging issues to be examined as to how the use of confidential information and the duty of confidentiality to the company by the employees associated with the principle of confidentiality and Law No. 30 of 2000 on Trade Secrets Jo Act No. 13 of 2003 on employment.

Trade secrets is one of the intellectual property rights granted protection by the state through legislation. However, as a result of unhealthy competition among businesses, especially competition in the field of construction business construction of public facilities, businesses make use of all means to win the tender held by the organizer of the tender including with or without the right to take / use of confidential information other companies in order to benefit as much as possible. The means used to obtain confidential infromasi economic value is done in many ways one of them to take advantage of workers / employees of the company owner is obliged to maintain information information. The use of confidential information by employees of the company is a violation of the principle of confidentiality and the provisions of the legislation, especially Trade Secrets Act and the Employment Act which requires the responsibility of the employees who use confidential information to the company of fellow bidders.
\end{abstract}

Keywords: Secret Information, The Responsibility Of The Employee. 


\section{A. PENDAHULUAN}

\section{Latar Belakang}

Persaingan merupakan bagian yang tidak terpisahkan dari kehidupan yang dihadapi para pengusaha dalam mencapai tujuan yaitu memperoleh laba yang sebesar-besarnya dan mengungguli perusahaan lain serta menjaga perolehan laba tersebut. Dalam mencapai tujuan tersebut, sering kali terjadi praktek persaingan curang yang dapat menimbulkan konflik antara pengusaha yang satu dengan pengusaha yang lain. ${ }^{1}$ Konflik itu juga dapat merugikan rakyat sebagai konsumen. Untuk mencegah dan mengatasi persaingan curang itu, diperlukan hukum yang akan menentukan rambu-rambu yang harus ditaati secara preventif dan represif bagi mereka yang melakukan persaingan. Tujuannya agar hukum dapat mencegah terjadinya persaingan curang. Lingkup tujuan di atas termasuk pula tindakan hukum terhadap pengusaha yang melakukan pelanggaran terhadap pemilik hak rahasia dagang. ${ }^{2}$ Pelanggaran terhadap rahasia dagang sering terjadi baik antara pengusaha dengan pengusaha, pengusaha dengan perorangan maupun pengusaha dengan karyawannya.

Salah satu contoh pelanggaran rahasia dagang pernah terjadi pada tahun 2012, yakni Ryan Alhadi adalah seorang karyawan yang dituntut oleh PT Muncul Pandanwangi sebuah perusahaan tempat dimana ia bekerja. PT Muncul Pandanwangi berkedudukan di Kabupaten Karawang yang beroperasi di bidang jasa kontruksi. Permasalahan dalam kasus ini adalah pembocoran rahasia dagang PT Muncul Pandanwangi yang dilakukan oleh Ryan Alhadi. Ryan Alhadi membocorkan rahasia perusahaan tempatnya bekerja kepada saingan perusahaannya. Pada bulan Maret 2012, Ryan Alhadi yang bekerja pada PT Muncul Pandanwangi membuat design, gambar, dokumentasi, kalkulasi harga untuk penyusunan proposal tender pembuatan jalan di PT Aksindo untuk

\footnotetext{
${ }^{1}$ Soedargo Gautama, Rizawanto Winata, Pembaharuan Hukum Merek Indonesia, PT Citra Aditya Bakti, Bandung, 1997, hal 5

2 Ahmad M. Ramli, H.A.K.I : Teori Dasar Perlindungan Rahasia Dagang, Mandar Maju, Banung, 2000, hal 1-2
} 
membangun jalan lingkungan di Desa Ciranggon Kecamatan Majalaya Kabupaten Karawang. Tanpa diketahui oleh PT Muncul Pandanwangi, Ryan Alhadi juga mengerjakan proposal yang sama untuk perusahaan saingan yaitu PT Baladewa dengan tujuan memenangkan tender dari PT. Aksindo yang sedang diikuti oleh PT Muncul Pandanwangi. PT Baladewa meminta Ryan Alhadi untuk mengerjakan proposal tersebut karena tidak mengetahui bahwa Ryan Alhadi adalah karyawan PT Muncul Pandanwangi dan Ryan mendapatkan bayaran sebesar Rp. 75.000.000,- dari PT Baladewa.

Perusahaan PT Muncul Pandanwangi mengalami kerugian, kemudian menuntut Ryan Alhadi di Pengadilan. Hakim memutuskan bahwa Ryan Alhadi telah terbukti secara sah dan meyakinkan bersalah melakukan tindak pidana dengan sengaja tanpa hak mengingkari kesepakatan untuk menjaga rahasia dagang, melakukan perbuatan sebagaimana yang dimaksud dalam Pasal 13 dan Pasal 14 sebagaimana diatur dan diancam pidana dalam Pasal 17 ayat (1) Undangundang RI No. 30 tahun 2000 tentang Rahasia Dagang, juga diatur dan diancam pidana sesuai Pasal 323 ayat (1) KUHP, dan menjatuhkan pidana terhadap terdakwa dengan pidana penjara selama satu tahun.

Penggunaan informasi yang bersifat rahasia milik perusahaan yang dibocorkan oleh seorang karyawan berdampak pada perusahaan pemilik informasi tersebut, dampaknya adalah perusahaan akan mengalami kerugian yang segnifikan karena informasi yang bersifat rahasia dan memiliki nilai ekonomi dibocorkan lebih dahulu oleh karyawan untuk kepentingan pribadinya. Keuntungan yang senyatanya akan didapat oleh perusahaan secara otomatis akan hilang karena informasi yang bernilai ekonomis telah dibocorkan pada perusahaan kompetitor sesama peserta tender. Oleh karena itu karyawan sebagai pihak yang membocorkan informasi kepada pihak lain dengan tanpa hak wajib dibebani tanggung jawab hukum karena melanggar berbagai peraturan perundangundangan yang berlaku khususnya undang-undang di bidang ketenagakerjaan dan undang-undang rahasia dagang. 
Dalam ketentuan perundang-undangan tentang ketenagakerjaan, Pasal 158 ayat (1) huruf i undang-undang No 13 tahun 2003 tentang Ketenagakerjaan menyatakan bahwa:

"Pengusaha dapat memutuskan hubungan kerja terhadap pekerja/buruh dengan alasan pekerja/buruh yang telah melakukan kesalahan berat seperti:

"Membongkar atau membocorkan rahasia perusahaan yang seharusnya dirahasiakan kecuali untuk kepentingan negara"

Selanjutnya ditinjau dari undang-undang No 30 tahun 2000 tentang Rahasia Dagang khususnya Pasal 13 mengatur bahwa:

"Pelanggaran Rahasia Dagang juga terjadi apabila seseorang dengan sengaja mengungkapkan Rahasia Dagang, mengingkari kesepakatan atau mengingkari kewajiban tertulis atau tidak tertulis untuk menjaga Rahasia Dagang yang bersangkutan"

Selain dalam Pasal 13 perbuatan dianggap sebagai pelanggaran rahasia dagang juga diatur dalam Pasal 14 Undang-undang No 30 tahun 2000 tentang Rahasia Dagang yang mengatur bahwa:

"Seseorang dianggap melanggar Rahasia Dagang pihak lain apabila ia memperoleh atau menguasai Rahasia Dagang tersebut dengan cara yang bertentangan dengan peraturan perundang-undangan yang berlaku”

Perbuatan sebagaimana diatur dalam ketentuan-ketentuan di atas, diancam dengan sanksi pidana sebagaimana diatur dalam Pasal 17 Undang-undang No 30 tahun 2000 tentang Rahasia Dagang yang mengatur bahwa:

"Barangsiapa dengan sengaja dan tanpa hak menggunakan Rahasia Dagang pihak lain ataumelakukan perbuatan sebagaimana dimaksud dalam pasal 13 atau Pasal 14 dipidanadengan pidana penjara paling lama 2 (dua) tahun dan/atau denda paling banyak Rp.300.000.000,00 (tiga ratus juta rupiah)"

Ketentuan di atas, merupakan upaya pemerintah dalam melindungi hak kekayaan intelektual seseorang atau korporasi yang bernilai ekonomi dalam apabila digunakan dalam bisnisnya. Ketentuan perundang-undangan yang mengatur tentang perlindungan rahasia dagang sejatinya harus ditaati oleh para 
pelaku usaha sebagai penghormatan terhadap hak kekayaan intelektual yang dimiliki seseorang.

Pada prakteknya setiap orang atau pihak dalam perusahaan (karyawan) yang melakukan penggunaan/membocorkan informasi yang bersifat rahasia milik perusahaan khususnya di kabupaten Karawang tidak dimintai pertanggung jawaban hukum baik perdata maupun pidana, padahal tindakan penggunaan informasi yang bersifat rahasia kepada perusahaan sesama peserta tender merugikan perusahaan pemilik informasi, padahal idealnya apabila seseorang melakukan perbuatan yang merugikan perusahaan dan melanggar perjanjian kerja atau peraturan perusahaan wajib dimintai pertanggung jawaban hukum karena karyawan telah melakukan tindakan wanprestasi terhadap perjanjian kerja untuk menjaga rahasia perusahaan.

\section{Identifikasi Masalah}

1. Bagaimana penggunaan informasi yang bersifat rahasia oleh karyawan dihubungkan dengan prinsip kerahasiaan dan Undang-undang No 30 Tahun 2000 Tentang Rahasia Dagang Jo Undang-undang No 13 Tahun 2003 Tentang ketenagakerjaan?

2. Bagaimana tanggung jawab karyawan yang menggunakan informasi rahasia di bidang jasa kontruksi kepada perusahaan sesama peserta tender yang merugikan perusahaan pemilik informasi ditinjau dari Undangundang No 30 Tahun 2000 Tentang Rahasia Dagang dan Undang-undang No 13 Tahun 2003 Tentang Ketenagakerjaan? 


\section{B. PEMBAHASAN}

\section{Penggunaan Informasi yang Bersifat Rahasia Oleh Karyawan Dihubungkan Dengan Prinsip Kerahasiaan dan Undang-undang No 30 Tahun 2000 Tentang Rahasia Dagang Jo Undang-undang No 13 Tahun 2003 Tentang Ketenagakerjaan}

Pelanggaran terhadap rahasia perusahaan yang digolongkan sebagai rahasia dagang yang terjadi di beberapa daerah di Indonesia banyak dilakukan oleh pihak internal dari perusahaan pemilik informasi rahasia, mereka adalah orang (karyawan) yang diberi jabatan struktural untuk membuat dan menjaga rahasia dagang tersebut agar tidak dipublikasikan kepada pihak lain dan digunakan untuk kepentingan komersial perusahaan. Pengungkapan rahasia dagang/informasi rahasia yang dilakukan oleh karyawan pemilik rahasia dagang adalah sebuah pelanggaran terhadap prinsip kerahasiaan yang seharusnya dipegang teguh oleh karyawan, karena baik secara hukum maupun moral/kesusilaan karyawan sudah terikat oleh perjanjian kerja tertulis yang telah disepakati bersama antara pengusaha dengan karyawan untuk menjaga rahasia dagang tersebut guna kepentingan komersial perusahaan.

Prinsip kerahasiaan diantaranya menyangkut hal-hal yang berkaitan dengan rahasia perusahaan serta rahasia jabatan dari setiap pegawai dan pihak yang terafiliasi dengan perusahaan. Rahasia perusahaan mengandung pengertian yakni segala sesuatu yang berhubungan dengan kegiatan produksi, metode/cara pembuatan produk dan hal-hal lain dari perusahaan yang menurut kelaziman dunia usaha tidak boleh secara terbuka diungkapkan kepada masyarakat, secara ringkasnya rahasia perusahaan adalah segala sesuatu yang berhubungan dengan keterangan mengenai kegiatan suatu perusahaan yang bisa memberikan keuntungan kepada perusahaan. Adapun mengenai pengertian yang menurut kelaziman wajib dirahasikan oleh perusahaan yaitu seluruh data dan informasi mengenai segala sesuatu yang berhubungan dengan proses produksi. ${ }^{3}$

\footnotetext{
${ }^{3}$ Muhammad Djumhana, Asas-asas Hukum Perbankan Indonesia, PT Citra Aditya Bakti, 2008, hal 202
} 
Secara umum kerahasiaan berkaitan dengan kepercayaan, karena itu pula rahasia perusahaan sebagai salah satu faktor untuk menjaga kepercayaan publik. Mengingat kerahasiaan tersebut utamanya untuk menjaga kepercayaan masyarakat. Dengan demikian titik fokus prinsip kerhasiaan dalam sebuah kegiatan usaha khususnya dalam rahasia dagang adalah bertujuan untuk melindungi kualitas informasi rahasia tersebut agar tidak dipergunakan oleh pihak lain atau perusahaan pesaing. Sehingga tidak berlebihan apabila pemerintah mengeluarkan Undang-undang No 30 tahun 2000 tentang Rahasia Dagang dan memberikan hak monopoli penuh kepada pemilik rahasia dagang untuk mempergunakan infromasi itu sendiri atau memberikan lisensi kepada pihak lain untuk menggunakannya dalam menjalankan usaha.

Pengungkapan atau penggunaan rahasia dagang/informasi yang bersifat rahasia oleh karyawan selain melanggar prinsip kerahasiaan juga melanggar ketentuan perundang-undangan khususnya Undang-undang No 30 Tahun 2000 tentang Rahasia Dagang dan Undang-undang No 13 tahun 2003 tentang Ketenagakerjaan.

Ditinjau dari segi Undang-undang Rahasia Dagang perbuatan karyawan yang mengungkapkan informasi rahasia milik perusahaan adalah perbuatan yang melanggar undang-undang khususnya Pasal 13 Undang-undang Rahasia Dagang yang mengatur bahwa:

"Pelanggaran rahasia dagang juga terjadi apabila seseorang dengan sengaja mengungkapkan rahasia dagang atau mengingkari kesepakatan, atau kewajiban yang tertulis atau tidak tertulis untuk menjaga rahasia dagang yang bersangkutan"

Ketentuan di atas, mengatur bahwa pelanggaran terhadap rahasia dagang bisa terjadi ketika seseorang dengan sengaja mengungkapkan rahasia dagang dengan mengingkari kesepakatan atau kewajiban tertulis. Dalam dunia ketenagakerjaan di Indonesia, setiap calon pegawai/karyawan yang akan menjadi tenaga kerja di sebuah perusahaan pastinya ia terlebih dahulu menyatakan janji 
dan kesepakatan terhadap perjanjian kerja dan menaati tata tertib serta peraturan perusahaan yang kemungkinan dalam peraturan perusahaan tersebut terdapat klausul yang membebankan kewajiban kepada pegawai/karyawan untuk menjaga informasi rahasia yang memberikan keuntungan komersial kepada perusahaan. Ketika janji untuk menjaga informasi rahasia tersebut tidak dipenuhi maka hal tersebut merupakan perbuatan yang melanggar hukum. Mengingat bahwa Undang-undang Rahasia Dagang memberikan kewenangan kepada pemilik informasi rahasia untuk memberikan rahasia dagang kepada pihak lain hanya dengan cara lisensi sesuai dengan ketentuan Pasal 4 huruf b Undang-undang No 30 Tahun 2000 tentang Rahasia Dagang yang mengatur bahwa:

"Pemilik rahasia dagang berhak untuk memberi lisensi kepada atau melarang pihak lain untuk menggunakan rahasia dagangnya atau melarang mengungkapkan rahasia dagang kepada pihak ketiga untuk kepentingan yang bersifat komersial"

Apabila seorang karyawan mengungkapkan rahasia dagang kepada pihak lain seperti perusahaan pesaing tanpa pemberian lisensi yang sah atau menggunakan rahasia dagang untuk mendapatkan keuntungan pribadi maka tindakan karyawan tersebut merupakan sebuah pelanggaran hukum karena akan menimbulkan kerugian kepada perusahaan pemilik rahasia dagang. Apabila pelanggaran terhadap rahasia dagang seperti yang demikian terjadi, maka pemilik rahasia dagang (perusahaan) dapat menggugat pelaku sesuai dengan Pasal 11 Undang-undang No 30 Tahun 2000 tentang Rahasia Dagang yang mengatur bahwa:

"Pemegang rahasia dagang atau penerima lisensi dapat menggugat siapapun yang dengan sengaja dan tanpa hak melakukan perbuatan sebagaimana dimaksud dalam Pasal 4 berupa ganti kerugian dan penghentian semua perbuatan sebagaimana dimaksud dalam Pasal 4 dan gugatan diajukan ke pengadilan niaga"

Pemberian lisensi oleh pemilik rahasia dagang merupakan hak monopoli yang dimiliki oleh pemilik informasi, karena pada bidang hak kekayaan intelektual tidak berlaku larangan praktek monopoli. Pemilik hak kekayaan intelektual boleh melakukan praktek monopoli dalam penggunaan haknya. 
Undang-undang bidang hak kekayaan intelektual mengatur bahwa pemilik hak kekayaan intelektual mempunyai hak eksklusif (exclusive right), yaitu hak menggunakan secara bebas kekayaan intelektualnya. Baik dengan cara usaha sendiri maupun memberikan lisensi kepada pihak lain untuk ikut memetik manfaat ekonomi atas kekayaan intelektualnya itu. Ini dapat menimbulkan konsekuensi bahwa hanya pihak tertentu saja yang dapat menggunakan kekayaan intelektual seseorang berdasarkan lisensi. Ini berarti monopoli atas suatu kekayaan intelektual dan ini tidak dilarang oleh undang-undang No 5 tahun 1999 tentang Larangan Praktek Monopoli dan Persaingan Usaha Tidak Sehat. ${ }^{4}$

Pembocoran atau penggunaan rahasia dagang oleh karyawan apabila ditinjau dari Undang-undang Ketenagakerjaan, dapat menjadi alasan pengusaha untuk melakukan pemutusan hubungan kerja dengan pekerja. Pemutusan hubungan kerja oleh pengusaha ialah PHK atau prakarsanya berasal dari pengusaha karena adanya pelanggaran atau kesalahan yang dilakukan oleh pekerja atau mungkin karena faktor-faktor lain, seperti pengurangan tenaga kerja, perusahaan tutup karena merugi, perubahan status dan sebagainya. Menurut Abdul Hakim PHK oleh pengusaha terbagi menjadi dua maca, yaitu sebagai berikut : 5

a. PHK karena kesalahan berat dan

b. PHK karena kesalahan ringan

Berdasarkan Pasal 151 Undang-undang No 13 tahun 2003 tentang Ketenagakerjaan PHK oleh pengusaha harus memperoleh penetapan terlebih dahulu dari lembaga penyelesaian hubungan industrial. Jadi, mem-PHK pekerja tidak bisa semau atau sekehendak pengusaha. Kesemuanya harus dilakukan dengan dasar dan alasan yang kuat. Tindakan membocorkan rahasia perusahaan merupakan salah satu jenis kesalahan berat yang dapat dijadikan alasan kuat oleh

\footnotetext{
${ }^{4}$ Abdulkadir Muhammad, Kajian Hukum Ekonomi Hak Kekayaan Intelektual, PT Citra Aditya Bakti, Bandung, 2001, hal 310

${ }^{5}$ Abdul Khakim, Hukum Ketenagakerjaan, PT Citra Aditya Bakti, Bandung, 2009, hal 193
} 
pengusaha untuk memutuskan hubungan kerja dengan pekerja sesuai ketentuan dalam Pasal 158 ayat (1) huruf i Undang-undang Ketenagakerjaan yang mengatur bahwa pengusaha dapat mem-PHK pekerja karena pekerja telah melakukan kesalahan berat diantaranya:

"Membongkar atau membocorkan rahasia perusahaan yang seharusnya dirahasiakan, kecuali untuk kepentingan negara"

Akan tetapi untuk melakukan PHK kepada pekerja yang sudah melakukan kesalahan berat berupa membocorkan informasi yang bersifat rahasia milik perusahaan, pengusaha harus memiliki bukti berupa pekerja tertangkap tangan, ada pengakuan dari pekerja atau bukti lain berupa laporan kejadian yang dibuat oleh pihak yang berwenang di perusahaan yang bersangkutan dan di dukung sekurang-kurangnya dua orang saksi. Dengan demikian, pemutusan hubungan kerja yang dilakukan pengusaha harus beralasan dan cukup bukti yang kuat.

Berdasarkan Surat Edaran Menteri Tenaga Kerja dan Transmigrasi No SE 13/Men/SJ-HK/I/2005 tentang Putusan Mahkamah Konstitusi atas Uji Materil Undang-undang No 13 tahun 2003 tentang Ketenagakerjaan terhadap Undangundang Dasar 1945, diatur bahwa untuk PHK oleh pengusaha karena alasan pekerja melakukan kesalahan berat hanya dapat dilakukan setelah adanya putusan hakim pidana yang telah mempunyai kekuatan hukum tetap (inkracht).

Oleh sebab itu, apabila pengusaha akan melakukan PHK kepada pekerja dengan alasan kesalahan berat, harus menempuh proses peradilan pidana terlebih dahulu, yaitu dengan cara mengadukan pekerja yang melakukan kesalahan berat tersebut kepada aparat yang berwajib. Dalam hal ini otomatis pengusaha dan pekerja harus menempuh proses hukum yang panjang dan memerlukan pengorbanan baik waktu, tenaga, maupun biaya yang tidak sedikit. Untuk menyikapi PHK seperti ini akhirnya kembali pada kesepakatan antara pengusaha dengan pekerja yang bersangkutan, bagaimana cara menyiasatinya dengan baik sehingga perselisihan PHK dapat selesai dengan praktis dan cepat. Menurut Abdul Hakim, bagaimanapun jika antara pengusaha dengan pekerja menempuh jalur pidana baru kemudian ke pengadilan hubungan industrial, tentu proses tersebut sangat melelahkan dan menyita waktu. Dalam kasus tertentu yang masih dalam 
batas toleransi bagi pengusaha lebih baik konsentrasi pada urusan perusahannya, sebaliknya juga bagi pekerja lebih baik cepat selesai urusan PHK-nya dan dapat segera mencari pekerjaan baru.

\section{Tanggung Jawab Karyawan yang Menggunakan Informasi di Bidang Jasa Kontruksi Kepada Perusahaan Sesama Peserta Tender yang Merugikan Perusahaan Pemilik Informasi Ditinjau Dari Undang- undang No 30 Tahun 2000 Tentang Rahasia Dagang dan Undang- undang No 13 Tahun 2003 Tentang Ketenagakerjaan}

Seseorang karyawan yang melakukan tindakan hukum dan tidak memenuhi kewajiban hukumnya, maka ia harus memikul tanggung jawab hukum. Pengungkapan informasi yang bersifat rahasia kepada perusahaan sesama peserta tender dengan tujuan mendapatkan keuntungan pribadi merupakan perbuatan yang melanggar hukum. Informasi rahasia sebuah perusahaan kontruksi merupakan salah satu bagian dari hak kekayaan intelektual. Permasalahan hak milik intelektual memang senantiasa berkembang seiring dengan perkembangan ilmu pengetahuan dan teknologi. Semakin berkembang ilmu pengetahuan dan teknologi, semakin dirasakan perlunya perlindungan terhadap hak milik intelektual. ${ }^{6}$

Menurut ketentuan Pasal 13 Undang-undang Rahasia Dagang menentukan bahwa pelanggaran rahasia dagang terjadi apabila seseorang dengan sengaja mengungkapkan rahasia dagang, mengingkari kesepakatan atau mengingkari kewajiban tertulis atau tidak tertulis untuk menjaga rahasia dagang yang bersangkutan. Selanjutnya menurut Pasal 14 Undang-undang Rahasia Dagang menentukan juga bahwa seseorang dianggap melanggar rahasia dagang pihak lain

\footnotetext{
${ }^{6}$ Neni Sri Imaniyati, Perlindungan Hak Milik Intelektual, Tantangan Indonesia Pada Ekonomi Global, dalam Kapita Selekta Hukum Perdata, Masalah Bisnis dalam Kajian Hukum, Fakultas Hukum, Universitas Islam Bandung, Bandung, 2004, hal 27
} 
apabila dia memperoleh atau menguasai rahasia dagang dengan cara yang bertentangan dengan peraturan perundang-undangan yang berlaku.

Untuk menuntut tanggung jawab dari pelaku pelanggaran rahasia dagang, maka menurut Pasal 11 Undang-undang Rahasia Dagang mengatur bahwa pemegang rahasia dagang atau penerima lisensi dapat menggugat siapapun yang dengan sengaja dan tanpa hak melakukan perbuatan sebagaimana diatur dalam Pasal 4 yaitu menggunakan rahasia dagang untuk kepentingan yang bersifat komersial atau mengungkapkan rahasia rahasia dagang kepada pihak ketiga untuk kepentingan yang bersifat komersial, berupa:

a. Gugatan ganti rugi atau

b. Penghentian semua perbuatan sebagaimana dimaksud dalam Pasal 4

Selain penyelesaian melalui gugatan sebagaimana dimaksud dalam Pasal 11, para pihak dapat menyelesaikan perselisihan tersebut melalui arbitrase atau alternatif penyelesaian sengketa (Pasal 12 Undang-undang Rahasia Dagang) yang dimaksud dengan alternatif penyelesaian sengketa adalah negosiasi, rekonsiliasi, dan cara lain yang dipilih oleh para pihak sesuai dengan undang-undang yang berlaku. Apabila terdapat dugaan telah terjadi pelanggaran hak rahasia dagang, maka menurut ketentuan Pasal 16 ayat (1) Undang-undang Rahasia Dagang akan dilakukan penyidikan oleh penyidik pejabat pegawai negeri sipil (penyidik PPNS) yang diberi wewenang khusus sebagai penyidik untuk melakukan penyidikan tindak pidana di bidang rahasia dagang.

Terhadap mereka yang ternyata terbukti telah melakukan tindak pidana pelanggaran hak rahasia dagang dituntut dan diancam dengan hukuman pidana sebagaimana diatur dalam Pasal 17 Undang-undang Nomor 30 Tahun 2000 Tentang Rahasia Dagang, yang menegaskan bahwa:

"Barang siapa dengan sengaja dan tanpa hak:

a. Menggunakan rahasia dagang pihak lain

b. Mengungkapkan rahasia dagang pihak lain

c. Mengingkari kesepakatan atau kewajiban menjaga rahasia dagang pihak lain

d. Jika rahasia dagang itu diperolehnya secara tidak patut atau bertentangan dengan peraturan perundang-undangan yang berlaku 
Dipidana dengan pidana penjara paling lama 2 (dua) tahun dan/atau denda paling banyak Rp. 300.000.000,00 (tiga ratus juta rupiah), tindak pidana tersebut merupakan delik aduan. ${ }^{7}$

Atas permintaan para pihak dalam perkara pidana maupun perkara perdata, hakim dapat memerintahkan agar sidang dilakukan secara tertutup. Ancaman pidana yang ditetapkan dalam Undang-undang No 30 Tahun 2000 tentang Rahasia Dagang merupakan langkah mundur dalam penegakan hukum hak kekayaan intelektual. Dalam rancangan undang-undang ancaman pidana ditetapkan maksimum 7 (tujuh) tahun penjara dan denda Rp. 300.000.000,00 (tiga ratus juta rupiah). Namun, dalam undang-undang Rahasia Dagang ancaman pidana justru diturunkan hanya ditetapkan maksimum 2 (dua) tahun penjara dan/atau denda Rp. 300.000.000.00 (tiga ratus juta rupiah). Sifat pidana adalah alternatif, sedangkan deliknya merupakan delik aduan. Dari sifat pidana yang diancamkan ada kemungkinan pelanggar hanya dikenai salah satu hukuman saja atau malah dibebaskan dari kedua pidana yang diancamkan. Kendatipun telah terjadi pelanggaran rahasia dagang di depan mata aparat penegak hukum, aparat tidak akan mengusut pelanggaran tersebut jika tidak ada pengaduan dari pihak yang dirugikan. Ancaman pidana tersebut bukan membuat pelanggarnya jera, melainkan berupaya melakukan pelanggaran, di sinilah letak kemunduran penegakan hukum dalam Undang-undang Rahasia Dagang.

Sementara itu berdasarkan Undang-undang No 13 Tahun 2003 tentang Ketenagakerjaan tidak mengatur tanggung jawab terhadap penggunaan informasi perusahaan yang dianggap sebagai rahasia dagang, hanya saja ketentuan Pasal 158 ayat (1) huruf i yang megatur bahwa pengusaha dapat memutuskan hubungan kerja dengan pekerja apabila pekerja melakukan kesalahan berat diantaranya mengungkapkan rahasia perusahaan yang diklasifikasikan sebagai rahasia dagang, selanjutnya proses hukum yang dijalankan untuk menuntut tanggung jawab pekerja menggunkana Undang-undang Rahasia Dagang.

\footnotetext{
${ }^{7}$ Pasal 17 Undang-Undang Nomor 30 Tahun 2000 Tentang Rahasia Dagang
} 
Tanggung jawab hukum karyawan yang mengungkapkan informasi rahasia perusahaan kontruksi yang memiliki nilai ekonomis apabila informasi tersebut digunakan dalam tender pembangunan fasilitas umum akan memberikan keuntungan pada perusahaan pemilik informasi perlu ditegakan secara tegas. Oleh karena itu, rahasia dagang yang sudah menjadi bagian dari hak kekayaan intelektual merupakan salah satu aspek hukum bisnis yang perlu mendapat perhatian dan perlindungan. Banyak karya-karya yang laihr atau dihasilkan oleh manusia melalui kemampuan intelektualnya, baik melalui daya cipta, rasa maupun karsanya. ${ }^{8}$ Perlindungan hukum terhadap hasil intelektual manusia seperti bidang perancangan kontruksi bangunan yang dibuat oleh perusahaan kontruksi bangunan perlu diperhatikan dengan serius. Sebab karya manusia ini telah dihasilkan dengan suatu pengorbanan tenaga, pikiran, waktu, bahkan biaya yang tidak sedikit.

\section{PENUTUP}

\section{Simpulan}

Penggunaan informasi yang bersifat rahasia milik perusahaan oleh karyawan adalah perbuatan yang melanggar prinsip kerahasiaan dan Undangundang Rahasia Dagang serta Undang-undang Ketenagakerjaan. Pengungkapan informasi yang bersifat rahasia kepada pihak lain hanya dapat dilakukan dengan cara pemberian lisensi oleh perusahaan pemilik informasi rahasia sesuai Pasal 4 Undang-undang Rahasia Dagang, dan pengungkapan informasi rahasia oleh karyawan dengan tanpa hak dapat menjadi alasan bagi perusahaan untuk melakukan pemutusan hubungan kerja (PHK) dengan karyawan sesuai Pasal 158 ayat (1) huruf i Undang-undang Ketenagakerjaan.

Karyawan yang tanpa hak menggunakan informasi rahasia di bidang jasa kontruksi yang merugikan perusahaan pemilik informasi menurut ketentuan Pasal 11 Undang-undang Rahasia Dagang dapat dimintai pertanggungjawaban berupa membayar ganti kerugian dan menghentikan semua kegiatan penggunaan

\footnotetext{
${ }^{8}$ Richard Burton Simatupang, Aspek Hukum dalam Bisnis, Rineka Cipta, Jakarta, 1996, hal 85
} 
informasi rahasia. Selain itu dapat dikenakan sanksi pidana penjara paling lama 2 (dua) tahun sesuai ketentuan Pasal 17 Undang-undang Rahasia Dagang.

\section{Saran}

1) Untuk pemerintah, upaya penegakan hukum di bidang rahasia dagang yang menjadi bagian dari hak kekayaan intelektual harus lebih diperkuat dengan merevisi ketentuan ancaman pidana bagi pelaku pelanggar rahasia dagang, karena ancaman sanksi pidana yang ada dalam rumusan Undang-undang Rahasia Dagang sangat ringan dan tidak menimbulkan efek jera bagi pelaku yang mengungkapkan atau menggunakan rahasia dagang yang bertentangan dengan ketentuan perundang-undangan yang berlaku.

2) Untuk masyarakat, khususnya para pelaku bisnis jasa kontruksi bangunan, kita tahu bahwa hak milik intelektual timbul atau lahir karena adanya kemampuan intelektualita seseorang. Oleh karena itu, maka sudah sepatutnya diantara para pelaku bisnis kontruksi bangunan harus saling menghormati hak kekayaan intelektual pesaing khususnya informasi yang bersifat rahasia. Hal ini bertujuan untuk menciptakan iklim persaingan usaha yang sehat diantara para pengusaha bisnis kontruksi bangunan.

\section{DAFTAR PUSTAKA}

\section{A. Buku}

Abdul Khakim, Hukum Ketenagakerjaan, PT Citra Aditya Bakti, Bandung, 2009

Abdulkadir Muhammad, Kajian Hukum Ekonomi Hak Kekayaan Intelektual, PT Citra Aditya Bakti, Bandung, 2001

Ade Maman Suherman, Aspek Hukum Dalam Ekonomi Global, Ghalia Indonesia, Bogor, 2002

Ahmad M. Ramli, H.A.K.I : Teori Dasar Perlindungan Rahasia Dagang, Mandar Maju, Banung, 2000 
Abdul Rachman Budiono, Hukum Perburuhan di Indonesia, PT Raja Grafindo Persada, Jakarta, 1995

Djumhana dan Djubaedah, Hak Milik Intelektual, Teori dan Prakteknya di Indonesia, PT Citra Aditya Bakti, Bandung, 1997

Muhammad Djumhana, Asas-asas Hukum Perbankan Indonesia, PT Citra Aditya Bakti, 2008

Neni Sri Imaniyati, Perlindungan Hak Milik Intelektual, Tantangan Indonesia Pada Ekonomi Global, dalam Kapita Selekta Hukum Perdata, Masalah Bisnis dalam Kajian Hukum, Fakultas Hukum, Universitas Islam Bandung, Bandung, 2004

Richard Burton Simatupang, Aspek Hukum dalam Bisnis, Rineka Cipta, Jakarta, 1996

Soedargo Gautama, Rizawanto Winata, Pembaharuan Hukum Merek Indonesia, PT Citra Aditya Bakti, Bandung, 1997

\section{B. Peraturan Perundang-undangan}

Kitab Undang - Undang Hukum Perdata

Undang - Undang Nomor 30 Tahun 2000 Tentang Rahasia Dagang

Undang - Undang Nomor 13 Tahun 2003 Tentang Ketenagakerjaan 